\title{
Impact of a Saline Mine Water Discharge on the Development of a Meromictic Pond, the Rontok Wielki Reservoir, Poland
}

\author{
Tadeusz Molenda ${ }^{1}$
}

Received: 27 February 2017 / Accepted: 5 June 2018 / Published online: 12 June 2018

(c) The Author(s) 2018

\begin{abstract}
A characteristic feature of the mines in the Upper Silesian Coal Basin in southern Poland is their highly saline mine water. In the past, this water was often discharged into anthropogenic reservoirs located a short distance from the mines, which completely changed the physicochemical properties of the water. In some cases, it also led to stratification of the reservoir waters, i.e. to the formation of meromictic water bodies. The Rontok Wielki reservoir, a former fish breeding pond, was converted into a settling tank for the highly saline $\left(\mathrm{Cl}^{-}=38,000 \mathrm{mg} / \mathrm{L}\right)$ water discharging from the Silesia Mine. The water in the tank stratified in three distinct zones: a mixolimnion, chemocline, and monolimnion. The saline mine water input ceased in 2003 and since then, there has been a gradual decrease in the electrical conductivity and $\left[\mathrm{Cl}^{-}\right]$in the reservoir waters. Moreover, meromixis has been entirely eliminated and freshwater breeding species have reappeared. A control, the Rontok reservoir, which was also a breeding pond, but was never used to settle saline mine water, was also studied for comparison.
\end{abstract}

Keywords Chlorides $\left(\mathrm{Cl}^{-}\right) \cdot$ Sodium $\left(\mathrm{Na}^{+}\right) \cdot$ Desalinisation $\cdot$ Water pollution $\cdot$ Hydrochemistry

\section{Introduction}

A characteristic feature of the mines in the Upper Silesian Coal Basin in southern Poland is their highly saline mine water (Różkowski 2004). Storage-dosing tanks were built and used to reduce the negative downstream impact of the discharge of saline waters. During times of low water flow in the river, the mine water was stored in these tanks until periods of high flow, so as to take advantage of dilution (Anielak 2000). In many cases, existing anthropogenic reservoirs, such as post-exploitation voids or fish breeding ponds, were adapted as storage-dosing tanks. This completely changed the physicochemical properties of the water in the ponds.

Although mine water is no longer discharged into these reservoirs, they are still saline and some of them are meromictic (Molenda 2014a). Meromixis in this climatic zone (mid-latitudes of the northern hemisphere) is a very rare phenomenon (Boehrer and Schulze 2008; Hutchinson 1957), as the entire mass of water in reservoirs (lakes) commonly mixes in spring and autumn (Hutchinson 1957). Meromixis

Tadeusz Molenda

tadeusz.molenda@us.edu.pl

1 Faculty of Earth Sciences, University of Silesia, Katowice, Poland has, however, been observed in post-exploitation excavations of lignite (Dietz et al. 2012; Jędrczak 1992), sulphur (Wilk-Woźniak and Żurek 2005; Żurek 2002), and gypsum (Madonia et al. 2006). Meromixis can also be caused by the inflow of highly contaminated groundwater into a reservoir (Galas 2003; Motyka and Postawa 2000), or leachate from landfills (Czop et al. 2011; Hrdinka et al. 2013). A special case is biogenic meromixis (Molenda 2015).

We examined the physicochemical properties and limnic processes in the storage-dosing Rontok Wielki reservoir, including the process of treating the reservoir water after the discharge stopped. The study also included a control, the Rontok tank, a nearby fish breeding pond that has never received mine water.

\section{Site Location}

The Rontok Wielki tank $\left(50^{\circ} 14^{\prime} 25.55^{\prime \prime} \mathrm{N}, 18^{\circ} 59^{\prime} 33.36^{\prime \prime} \mathrm{E}\right)$ is located in Rudołtowice (Fig. 1). The tank was a typical pond, built in the seventeenth century for fish farming. Water is supplied via drainage of the first groundwater aquifer (a sand reservoir) and inflow from a small watercourse. In hydrological terms, it is a through-flow water body, with 
Fig. 1 Localization of investigated reservoirs: 1 -fish ponds, 2-streams, 3-roads, 4-Coal Mine "Silesia", 5-mining waste dump, 6-direction of mining waters discharge, 7points of sampling

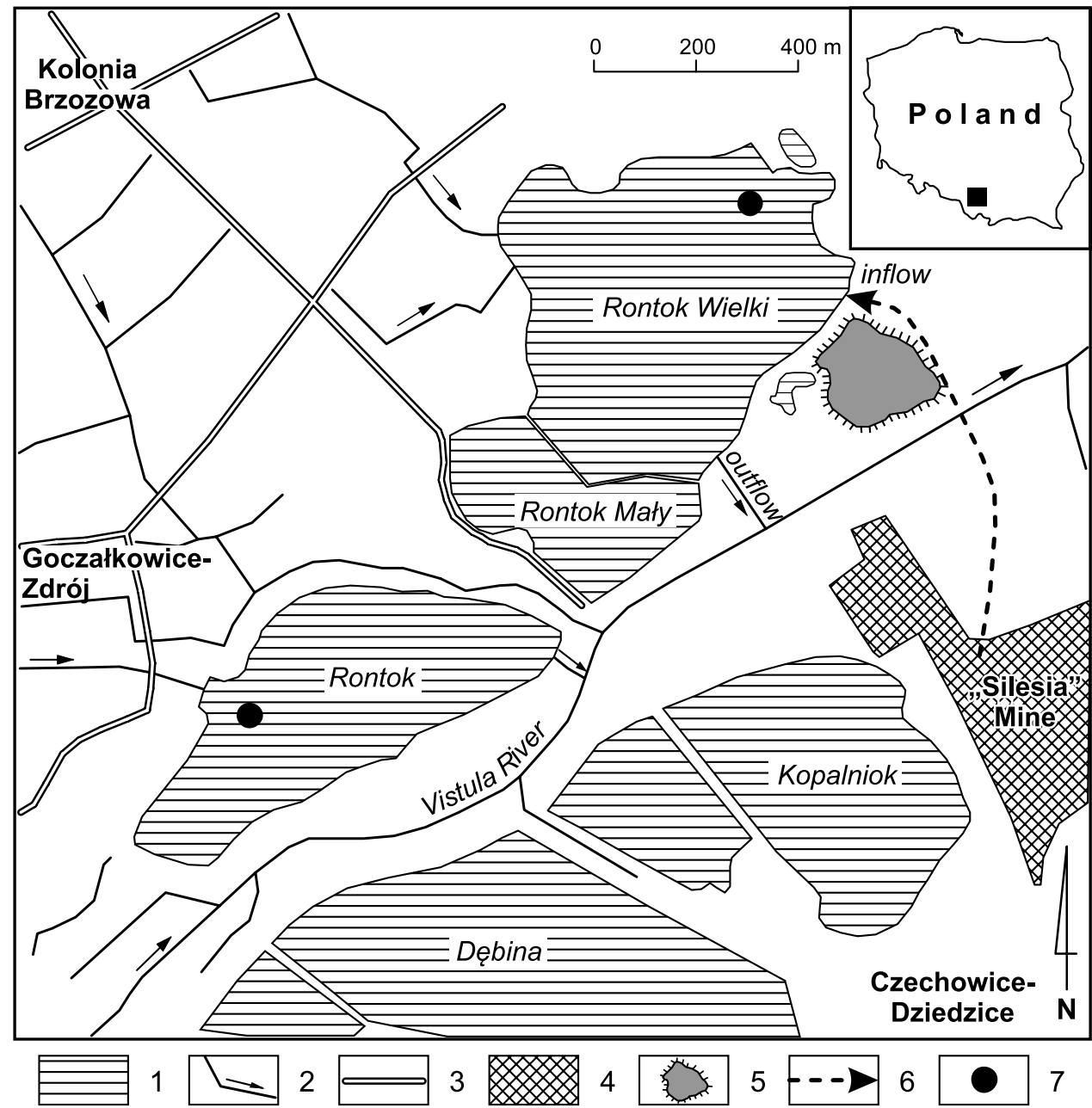

the outflow to the Vistula River (Fig. 1). The surface area of the reservoir is $0.32 \mathrm{~km}^{2}$, and a maximum depth is $3.0 \mathrm{~m}$.

During the 1970s, the Rontok Wielki fish breeding pond was adapted to be a settling tank for the Silesia Mine. Adaptation of the pond included constructing new, higher dikes (embankments). However, due to concerns of brine infiltration into nearby peat deposits (used in medical treatments), the storage-dosing function was turned to a mechanical function. The water discharged into the reservoir was saline, with an average electrolytic conductivity (EC) of $74 \mathrm{mS} /$ $\mathrm{cm}$ and an average chloride concentration of $38,000 \mathrm{mg} / \mathrm{L}$ (Materiały KWK "Silesia" 1990). In 2003, a new settling tank was built for the mine water and discharge to the reservoir ceased.
The Rontok pond, adjacent to Rontok Wielki, was used as a control (Fig. 1). This reservoir only received natural (fresh) water, and did not receive mine water. Both tanks are located in the temperate zone of the northern hemisphere, with four distinctive seasons (Table 1).

\section{Research Methods}

Measurements of basic physical and chemical properties of water (temperature, EC) were carried out directly in the field by a multiparameter probe EDS 6600 by YSI (manufactured by the USA) and Multiline P4 by WTW (manufactured by the Germany). Before each test, the probe was calibrated

Table 1 Climate characteristics

\begin{tabular}{llllllllllllll}
\hline Month & Jan & Feb & Mar & Apr & May & Jun & Jul & Aug & Sep & Oct & Nov & Dec & Year \\
\hline Mean air temp $\left({ }^{\circ} \mathrm{C}\right)$ & -3.3 & -2.1 & 1.9 & 7.6 & 13.0 & 16.5 & 18.0 & 17.3 & 13.6 & 8.1 & 3.4 & -0.6 & 7.8 \\
Mean precipitation $(\mathrm{mm})$ & 49 & 46 & 41 & 37 & 40 & 49 & 85 & 89 & 105 & 88 & 53 & 50 & 731 \\
Mean wind speed $(\mathrm{m} / \mathrm{s})$ & 3 & 3 & 3.1 & 4 & 2.3 & 2.3 & 3 & 2.0 & 2.0 & 4 & 2.4 & 2.9 & 2.8 \\
\hline
\end{tabular}


using standard solutions. Water parameters were determined in the tank along a vertical column every $0.5 \mathrm{~m}$ for $3 \mathrm{~m}$ at a point in the deepest point of the reservoir. The study was conducted in spring and autumn (mixing periods).

Water samples were also collected for chemical analysis. Water from the upper $0.5 \mathrm{~m}$ was collected using a telescopic boom, stored in polyethylene bottles, and transported to the laboratory at a temperature of $+4{ }^{\circ} \mathrm{C}$. Before analysis, the samples were filtered through a $0.45 \mu \mathrm{m}$ filter (Millipore). Laboratory analysis included determination of major anions and cations in the water: $\mathrm{Ca}^{2+}, \mathrm{Mg}^{2+}, \mathrm{Na}^{+}, \mathrm{K}^{+}, \mathrm{HCO}_{3}{ }^{-}$, $\mathrm{SO}_{4}{ }^{2-}$, and $\mathrm{Cl}^{-}$. The analyses were performed on an ion chromatograph Metrohm 850 Professional IC. Classification of hydrochemical types of water was based on the classification by Shchukaryev and Pryklonsky (Macioszczyk 1987). The analysis also took advantage of archival materials on the physicochemical properties of the mine water during operation of the tank. This study relies on archived materials for the 2001-2003 data, while our own research was conducted 2004-2010. The analytical procedures were the same as Molenda (2014a).

All statistical analyses were performed using the R program (R Development Core Team 2009). To check the significance of differences, a nonparametric equivalent of analysis of variance - the Kruskal-Wallis test was used, and for multiple comparisons- the Conover test. All data is presented using box-and-whisker plots.

\section{Results and Discussion}

The saline mine waters that entered Rontok Wielki had a strong EC (averaging $74 \mathrm{mS} / \mathrm{cm}$ ) and a high concentration of chloride $\left(\mathrm{Cl}^{-}\right)$ions (averaging 38,000 mg/L). This discharge changed the physicochemical properties of the pond waters, as can be seen by comparison with the Rontok control pond (Figs. 2, 3). However, there were no statistically significant differences in sulphate (Fig. 4). Mine water from the Silesia Mine had low concentrations of this ion, especially when compared with water from other mines in the Upper Silesian Coal Basin, where the sulphate concentrations in mine water can reach several thousand mg/L (Różkowski 2004).

The waters of the Rontok Wielki reservoir became a chloride-sodium type $\left(\mathrm{Cl}^{-}-\mathrm{Na}^{+}\right)$, while the waters of the Rontok control reservoir are a bicarbonate-calcium type $\left(\mathrm{HCO}_{3}{ }^{-}-\mathrm{Ca}^{2+}\right)$. A chloride-sodium type of water $\left(\mathrm{Cl}^{-}-\mathrm{Na}^{+}\right)$ is characteristic of many mines in the Upper Silesian Coal Basin (Różkowski 2004).

In 2003, the discharge of saline mine water into Rontok Wielki was discontinued and the tank ceased to operate. As a result, the salinity of its waters started to decrease (Fig. 5). The supply of fresh meteoric and groundwater and pond outflow resulted in the tank water becoming less saline over

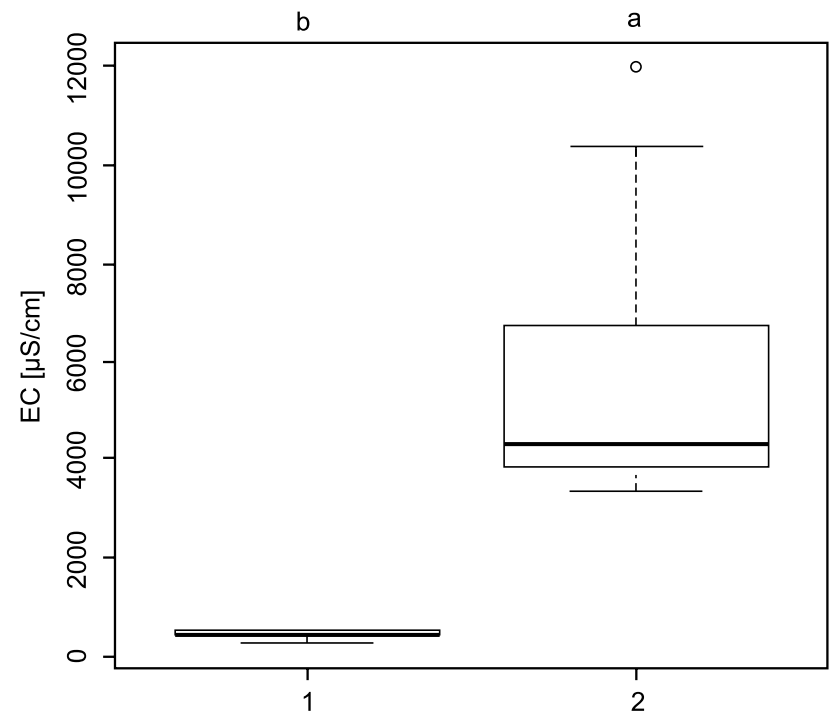

Fig. 2 Electrical conductivity (EC): 1-Rontok, 2-Rontok Wielki $(n=12)$

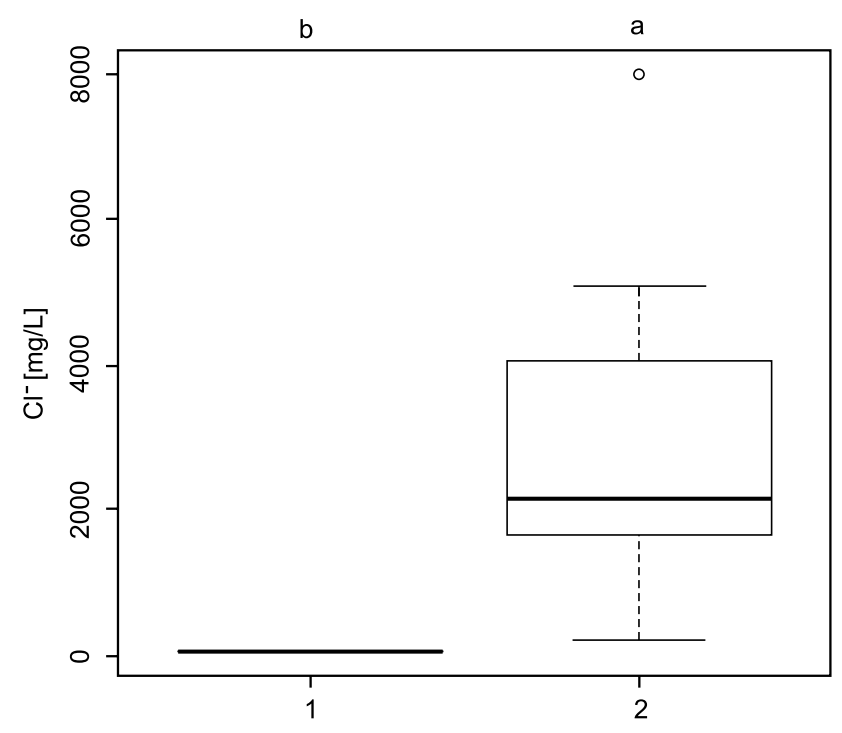

Fig. 3 Concentration of chlorides in waters of studied reservoirs: $1-$ Rontok, 2-Rontok Wielki $(\mathrm{n}=12)$

time (Fig. 6); a lower $\mathrm{Cl}^{-}$concentration was recorded in each successive year. It is also noted that while the reservoir was operating, until $2003, \mathrm{Cl}^{-}$showed a much greater range between spring and autumn measurements (Fig. 6), due to mine water discharges of varying salinity.

No downward trend was recorded for sulphate and there was still a significant spread between the concentrations recorded in spring and autumn, even after the reservoir had been put out of service (Fig. 7). This indicates that sulphate was, and is, coming from other sources. In the immediate vicinity of the reservoir, there is a mine waste landfill 


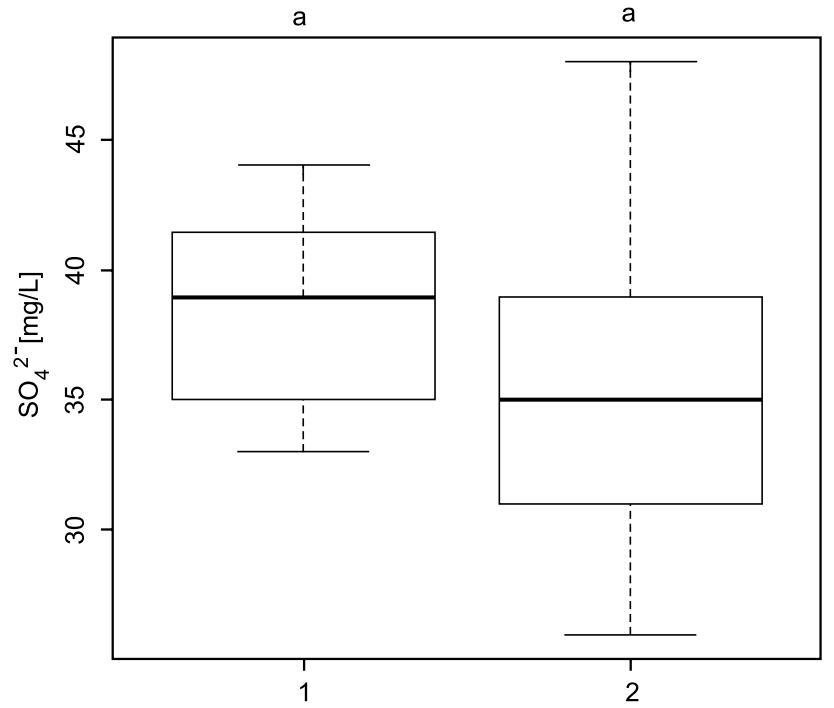

Fig. 4 Concentration of sulphate in waters of studied reservoirs $1-$ Rontok, 2-Rontok Wielki $(\mathrm{n}=12)$

(Fig. 1), where a Carboniferous mixture of shale, siltstone, and sandstone is deposited. Numerous studies (Molenda 2014b; Chmura and Molenda 2012) indicate that the water leaching from the mine waste is an important sulphate source.

Very large differences in the vertical profile of EC were recorded in Rontok Wielki, despite a very shallow tank $\left(\mathrm{h}_{\max } 3.0 \mathrm{~m}\right)$; complete water mixing did not take place, even shortly after cessation of the tank operation, in
Autumn, 2004 (when the difference in the EC between the water surface and bottom layer was $37 \mathrm{mS} / \mathrm{cm}$ ) and Spring, 2006 (when the difference was $52.8 \mathrm{mS} / \mathrm{cm}$; Fig. 8).

The water in the tank could be divided into three characteristic zones: the mixolimnion (to a depth of $\sim 1 \mathrm{~m}$ ), chemocline ( $\sim 1$ to $2 \mathrm{~m}$ ), and monimolimnion (below $2 \mathrm{~m})$. Such a distribution of EC in the vertical column clearly indicates a meromictic water body. In a normal lake or reservoir, complete mixing and homogenisation of the physicochemical properties of the water should take place in spring and autumn, such as observed in the Rontok reservoir, which does not receive mine water (Fig. 9). Large differences in EC in a vertical column of the tank (during spring and autumn homothermis) are one of the main criteria that allow identification of meromictic water bodies (Dietz et al. 2012; Espana et al. 2009; Żurek 2002; Hrdinka et al. 2013; Molenda 2014a, 2015; Hongve 1980; Kazanci et al. 2008).

The thermal profiles are also noteworthy. Both in autumn 2004 and spring 2006, water temperature in the vertical profile in the Rontok Wielki tank was not uniform (Fig. 10). It reached $10-12{ }^{\circ} \mathrm{C}$ at the bottom, while the upper $2 \mathrm{~m}$ were $4{ }^{\circ} \mathrm{C}$. In the Rontok tank, classic homothermis occurred and the water temperature in the entire profile was $4{ }^{\circ} \mathrm{C}$ (Fig. 11). A similar anomaly was also found by Molenda (2014a) in another saline meromictic reservoir. Another thermal anomaly appeared in summer 2004 , when a temperature of $22{ }^{\circ} \mathrm{C}$ was recorded at a depth of $1.5 \mathrm{~m}$ (Fig. 10). Temperature rise in the chemocline has also been detected in other meromictic reservoirs (Skowron 1995; Molenda 2014a).

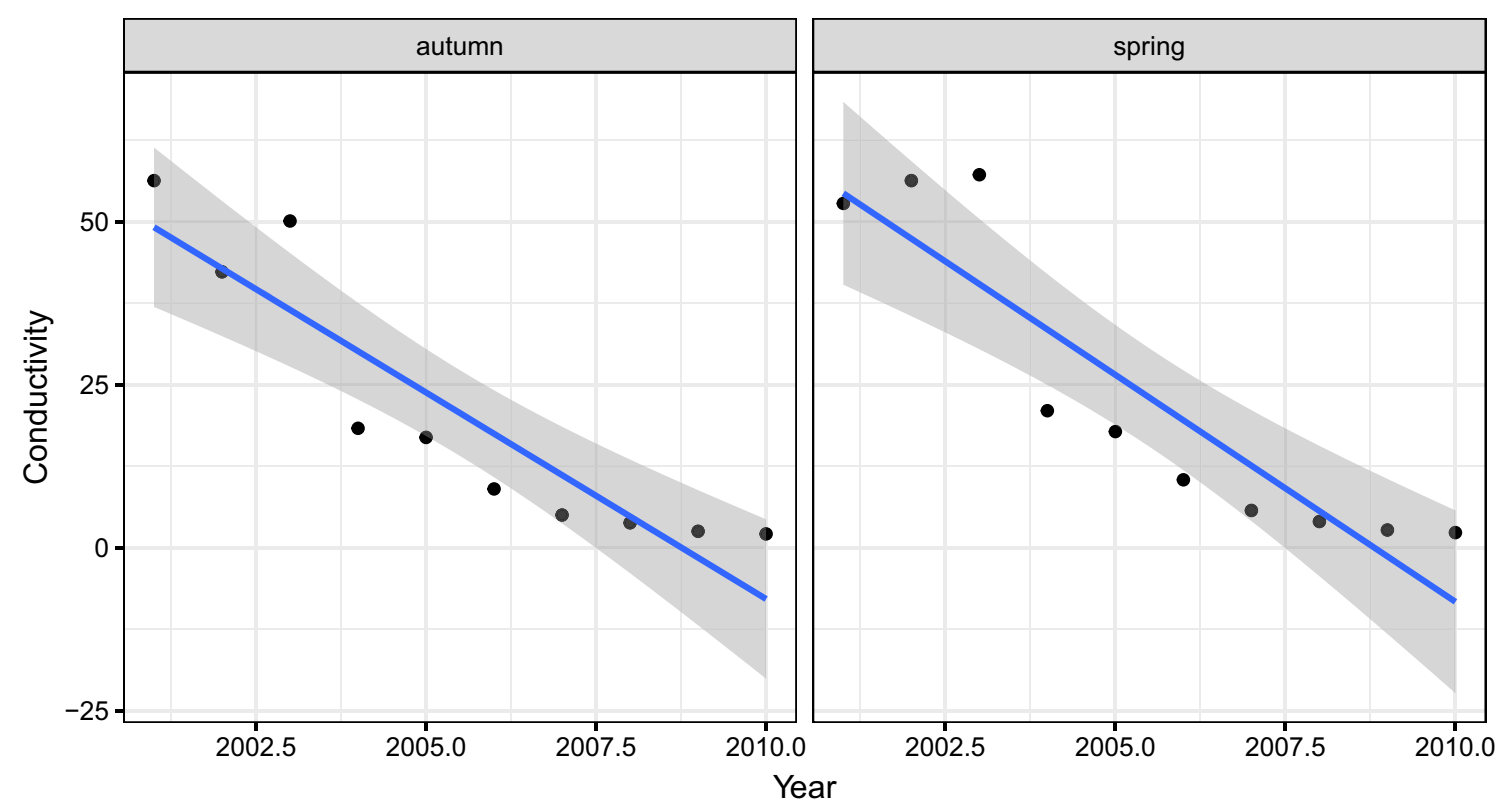

Fig. 5 Changes of electrolytic conductivity [mS/cm] of water pond "Rontok Wielki" in the years 2001-2010 (according to Molenda 2011; modified) 

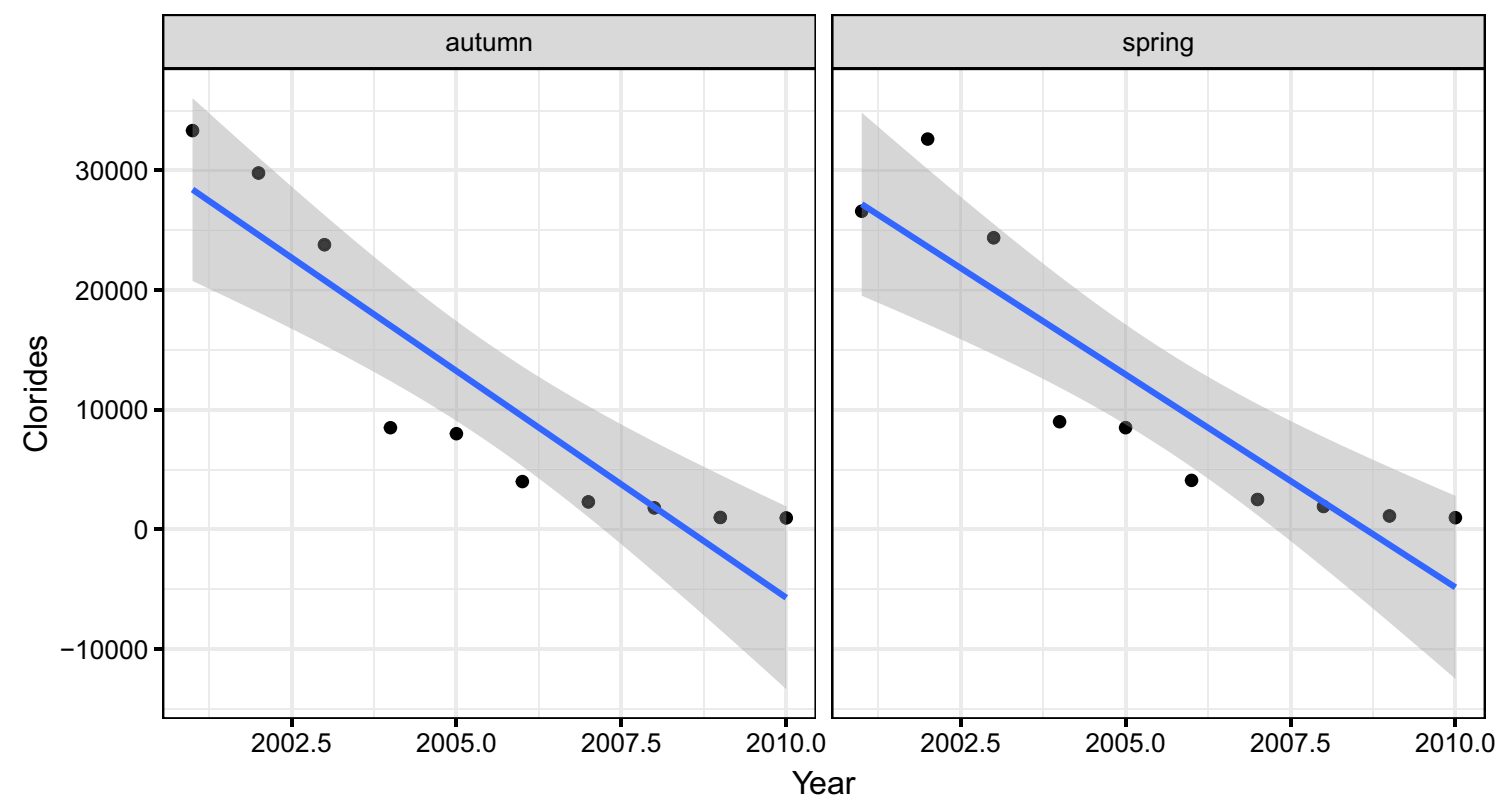

Fig. 6 Changes of the concentration of chlorides [mg/L] in the water of the pond "Rontok Wielki" in the years 2001-2010 (according to Molenda 2011, modified)
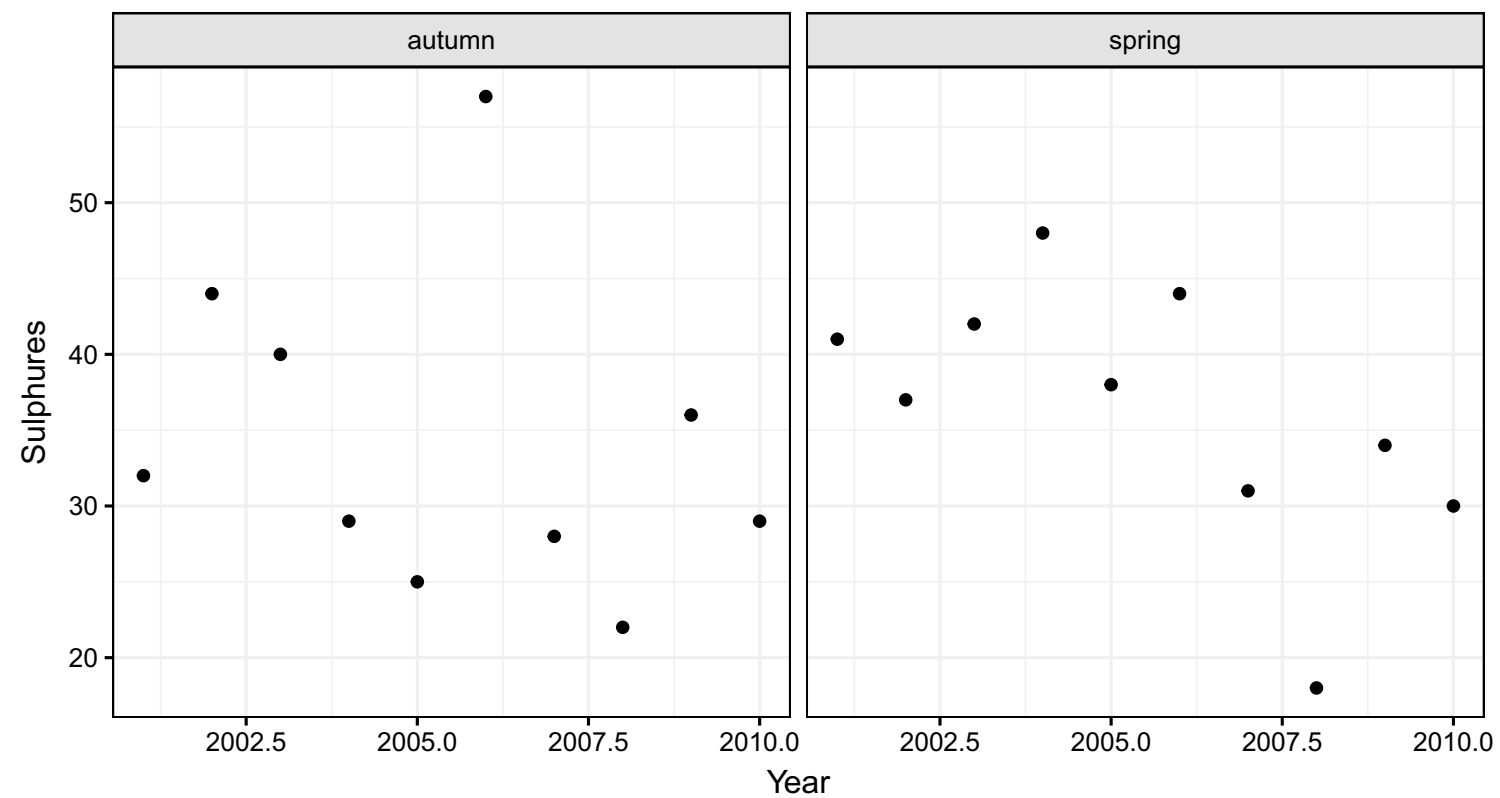

Fig. 7 Changes of the concentration of sulfate $[\mathrm{mg} / \mathrm{L}]$ in the water of the pond "Rontok Wielki" in the years 2001-2010 (according to Molenda 2011; modified)

Complete disturbance of the permanent stratification of water in the Rontok Wielki reservoir took place in spring 2007 , i.e. four years after the tank was taken out of service. In spring 2007, homogenous EC values and temperatures were recorded throughout the vertical profile (Figs. 8, 10). Since then, total mixing of the water 


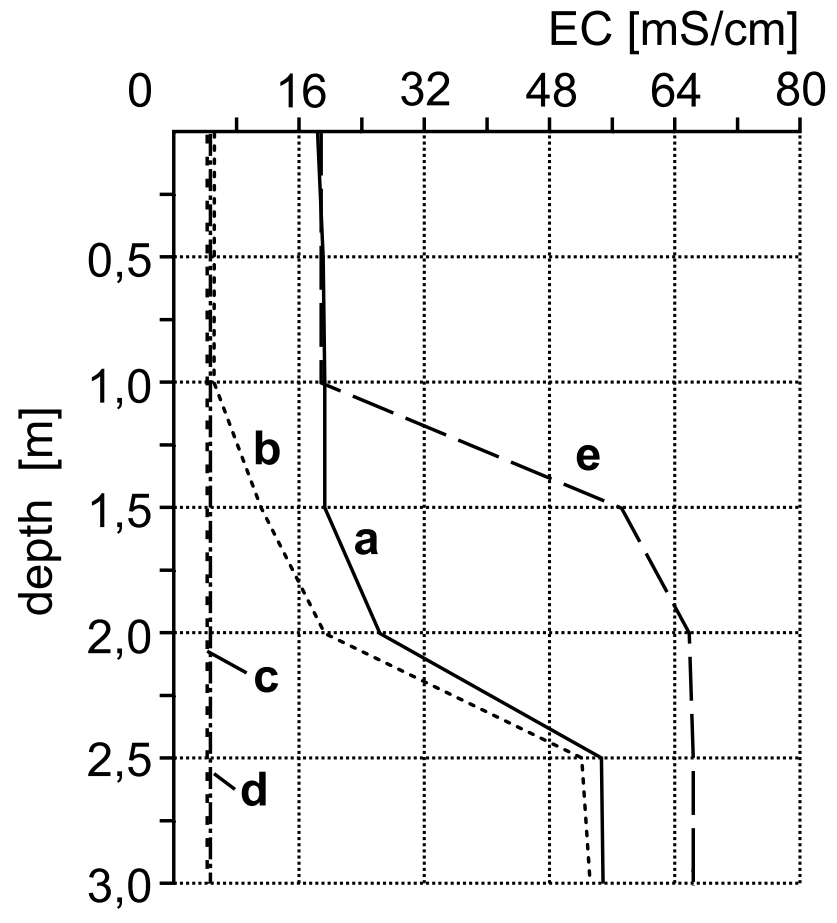

Fig. 8 Electric conductance profiles of "Rontok Wielki": a-autumn 2004, b-spring 2006, c-spring 2007, d-spring 2009, e-summer 2004 (according to Molenda 2011; modified)

has been recorded in spring and autumn. The tank is now regarded as holomictic.

After saline discharges to the reservoir ceased, appropriate freshwater breeding species reoccurred, so that the reservoir could regain the function of a breeding pond. Some of the freshwater fish that have appeared are Аmeiurus nebulosus and Gasterosteus aculeatus.

\section{Summary}

The results indicate that the discharge of saline mine waters to anthropogenic reservoirs can cause meromixis. In the case of through-flow reservoirs, when they cease to operate, salinity will begin to decrease. Thus, they differ

\section{$\mathrm{EC}[\mathrm{mS} / \mathrm{cm}]$}

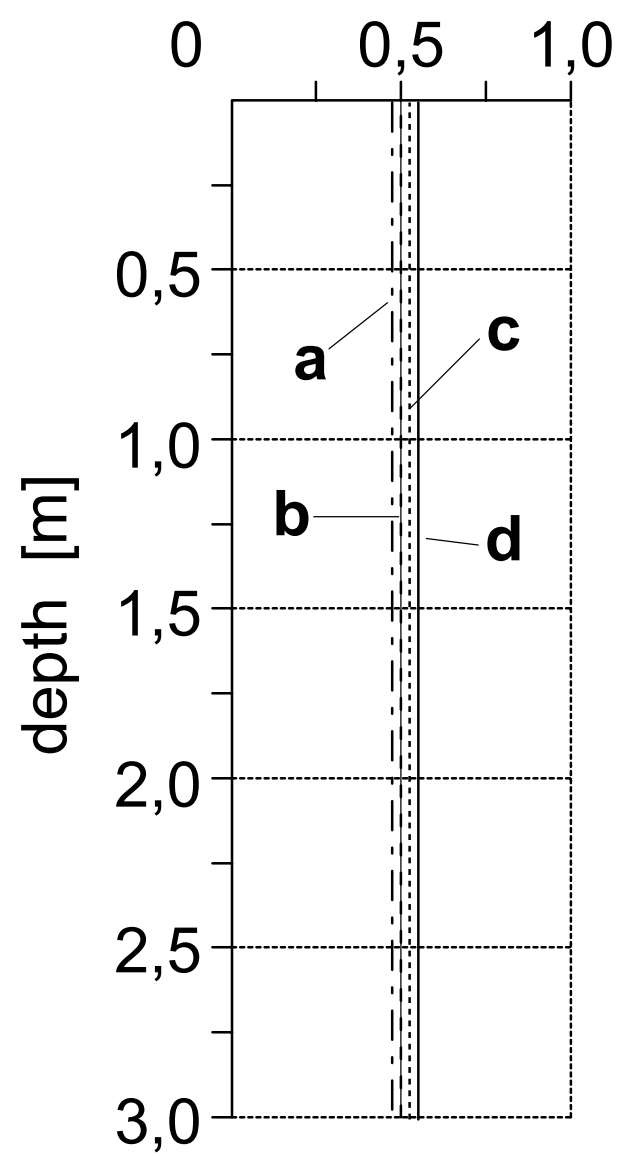

Fig. 9 Electric conductance profiles of "Rontok": a-autumn 2004, b-spring 2006, c-autumn 2008, d-spring 2009

from endorheic settling tanks where there was no decrease in salinity and disappearance of meromixis (Molenda 2014a). The rate of decreasing salinity depends on: the volume and salinity of stored water, the amount of inflowing freshwater (water exchange rate), and the morphometric features of the tank (e.g. wind mixing). 


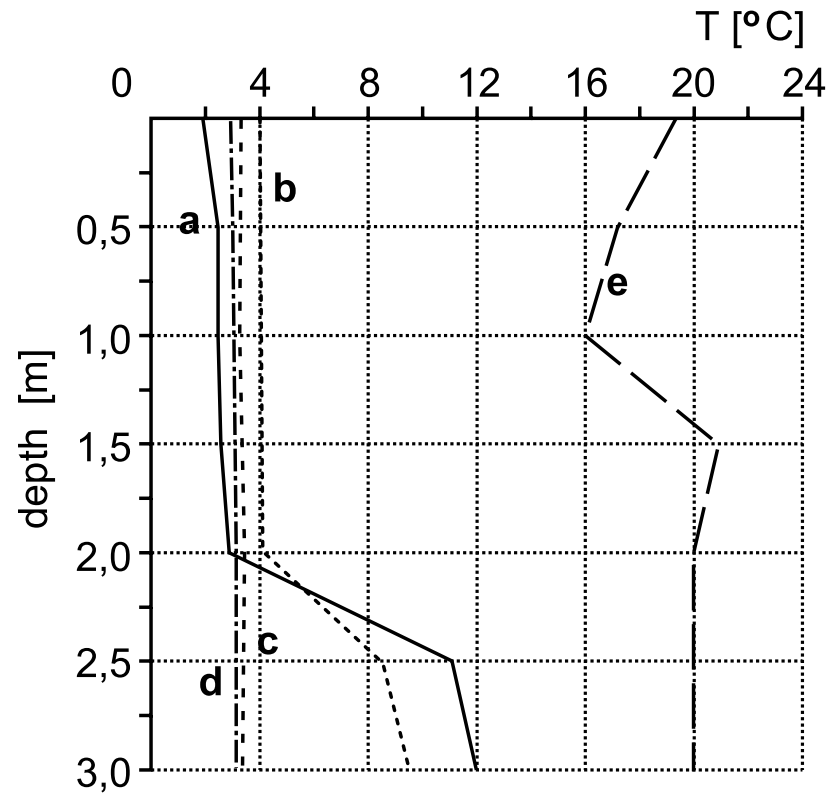

Fig. 10 Temperature profiles in "Rontok Wielki": a-autumn 2004, b-spring 2006, c-spring 2007, d-spring 2009, e-summer 2004 (according to Molenda 2011; modified)

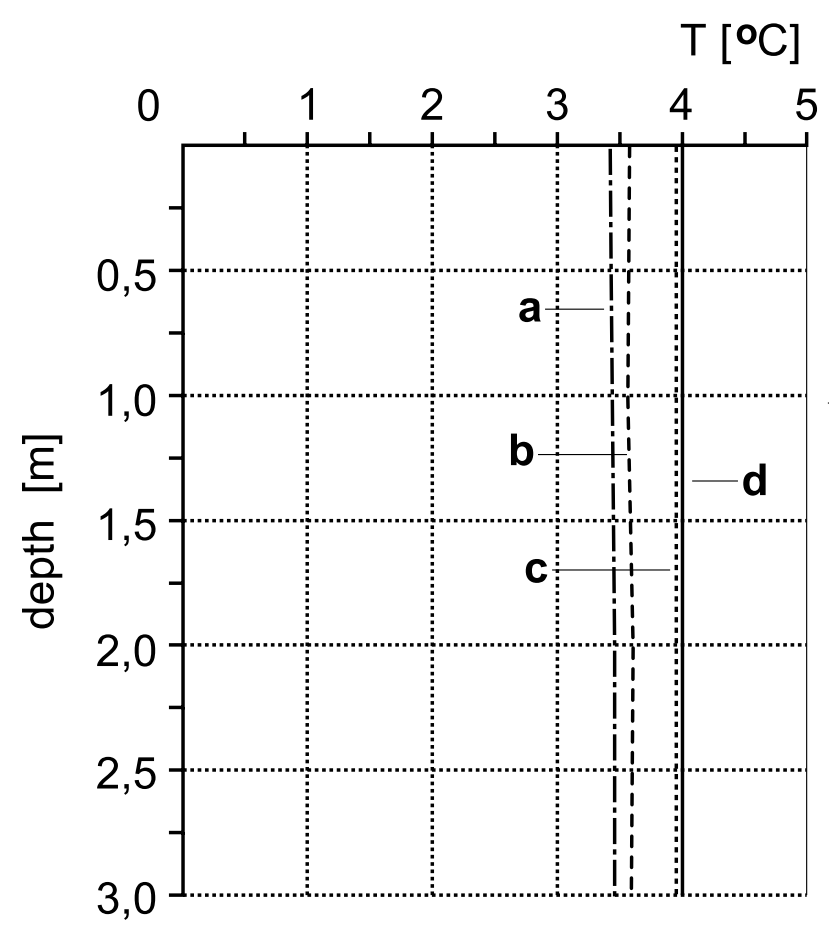

Fig. 11 Temperature profiles in "Rontok": a-autumn 2004, bspring 2006, c—autumn 2008, d—spring 2009

Acknowledgements The publication was partially financed with funds from the Leading National Research Centre (KNOW) received by the Centre for Polar Studies of the University of Silesia, Poland.
Open Access This article is distributed under the terms of the Creative Commons Attribution 4.0 International License (http://creativeco mmons.org/licenses/by/4.0/), which permits unrestricted use, distribution, and reproduction in any medium, provided you give appropriate credit to the original author(s) and the source, provide a link to the Creative Commons license, and indicate if changes were made.

\section{References}

Anielak A (2000) Chemiczne i fizykochemiczne oczyszczanie ścieków. PWN, Warszawa (in Polish)

Boehrer B, Schulze M (2008) Stratification of lakes. Rev Geophys 46:RG2005. https://doi.org/10.1029/2006RG000210

Chmura D, Molenda T (2012) Influence of thermally polluted water on the growth of helophytes in the vicinity of a colliery waste tip. Water Air Soil Pollut 223(9):5877-5884

Czop M, Motyka J, Szacek O, Szuwarzyński M (2011) Geochemistry of the hyperalkaline Gorka 4 in the Chrzanow 4egion. Southern Poland. Water Air Soil Pollut 214:423-434

Dietz S, Lessmann D, Boehrer B (2012) contribution of solutes to density stratification in a meromictic lake (Waldsee/ Germany). Mine Water Environ 31:129-137

Espana JS, Pamo EL, Diez M, Samtofimia E (2009) Physico-chemical gradients and meromictic stratification in Cueva de la Mora and other acidic pit lakes of the Iberian Pyrite Belt. Mine Water Environ 28:15-29

Galas J (2003) Limnological study on a Lake Fordem in a limestone quarry (Kraków, Poland). I water chemistry. Polish J Env Stud 12(3):297-300

Hongve D (1980) Chemical stratification and stability of meromictic in the Upper Romerike district. Aq Sci 42(2):171-195

Hrdinka T, Sobr M, Fott J, Nedbalova L (2013) The unique environment of the most acidified permanently meromictic lake in the Czech Republic. Limnologica 43:417-426

Hutchinson GE (1957) A treatise on limnology, vol 1. Wiley, New York City

Jędrczak A (1992) Skład chemiczny wód pojezierza antropogenicznego w Łuku Muzakowskim. Wydawnictwo Wyższej Szkoły Inżynierskiej, Zielona Góra (in Polish)

Kazanci N, Muzaffer D, Sonmez G (2008) The physico-chemical and biological characteristics of Koycegiz Lake in southwestern Turkey between 1991 and 1993 and future management proposals. Rev Hydrobiol 2:165-205

Macioszczyk A (1987) Hydrogeochemia. Wydawnictwa Geologiczne, Warszawa (in Polish)

Madonia P, Naselli-Flores L, Parello F, Parlato B (2006) Geological development of a gypsum lake formed at the beginning of the 20th century in central Sicily, Italy: integration of historical data with modern survey techniques. Chem Ecol 22(1):333-347

Materiały KWK "Silesia” (1990) Czechowice-Dziedzice (in Polish)

Molenda T (2011) Naturalne i antropogeniczne uwarunkowania zmian właściwości fizyczno-chemicznych wód w pogórniczych środowiskach akwatycznych. Na przykładzie regionu górnośląskiego i oszarów ościennych, Uniwersytet Śląski, Wydawnictwo Gnome, Katowice (in Polish)

Molenda T (2014a) Impact of saline mine water: development of a meromictic reservoir in Poland. Mine Water Environ 33:327-334

Molenda T (2014b) Analysis of concentrations heavy metals ( $\mathrm{Zn}, \mathrm{Pb}$, $\mathrm{Cu}, \mathrm{Cd}$ ) in spoil tip leachate from coal mining. In: Proc, international multidisciplinary scientific geoconferences, vol 1, hydrology and water resources, Albena-Bulgaria, pp 35-42 
Molenda T (2015) Conditions for development of anthropogenic meromictic reservoirs in the workings of crystalline rocks (based on the examples of the quarries of the Zulowska pahorkatina, NE Czech Republic). Environ Earth Sciences 74(3):2259-2271

Motyka J, Postawa A (2000) Influence of contaminated Vistula River water on the groundwater entering the Zakrzówek limestone quarry. Cracow region. Poland. Environ Geol 39(3/4):398-404

R Development Core Team (2009) R. A language and environment for statistical computing. R Foundation for Statistical Computing, Vienna

Różkowski A (2004) Środowisko hydrogeochemiczne karbonu produktywnego Górnośląskiego Zagłębia Węglowego. Wydawnictwo Uniwersytetu Śląskiego, Katowice (in Polish)
Skowron R (1995) Dynamika temperatury wody i zasobów ciepła w meromiktycznym jeziorze strefy polarnej (NW Spitsbergen) w okresie lata polarnego. In: XXII Sympozjum Polarne-Jedność środowiska przyrodniczego Arktyki i Antarktyki, Zamek Książ, 27-28.X.1995, pp 69-83 (in Polish)

Wilk-Woźniak E, Żurek R (2005) Phytoplankton and its relationships with chemical parameters and zooplankton in meromictic reservoir. Aquat Ecol 40:165-176

Żurek R (2002) Peculiarities of a sunken sulphur strip mine (Reservoir Piaseczno, southern Poland). In: Proceeding of the Review Conference on the scientific co-operation between Austria and Poland, Ecology and Technologies, Vienna, 24-28 Feb 2002 